\title{
A comment on 'Endogenous money and effective demand': a revolution or a step backwards?
}

\author{
Marc Lavoie \\ Professor of Economics, University of Ottawa, Canada
}

\begin{abstract}
Steve Keen argues that post-Keynesians have not sufficiently emphasized the revolutionary character of endogenous money for macroeconomic theory, and that this should be done by recognizing that aggregate demand is equal to current or past income plus the change in debt. This equation, attributed in particular to Hyman Minsky, is discussed and questioned, and it is recalled that a similar equation had been proposed by Alfred Eichner. The consequences of bank credit for firms or households are further analysed within the context of the national accounts, and it is shown that one does not need a redefinition of aggregate demand and aggregate supply, in contrast to what is proposed by Keen.
\end{abstract}

Keywords: bank credit, endogenous money, aggregate demand, time lags

JEL codes: $E 12, E 44, E 51$

\section{INTRODUCTION}

I have been asked by the editors of the journal to write a comment on Steve Keen's article (2014a, this issue). Heterodox economists are certainly grateful to Steve Keen for having induced Paul Krugman to present his views of bank lending and thus reveal that he had a rather limited knowledge of central bank operational procedures and of the mechanics of money creation. ${ }^{1}$ When I was young and daring, I wrote that one of the most dangerous things to do when studying money matters is to rely on the writings of Nobel laureates (Lavoie 1985, p. 63). Krugman, despite being a luminary among neoclassical Keynesians, and despite the fact that his current policy advice is much in line with that of post-Keynesians, is no different from his predecessors.

I am rather unclear about the true intended audience of Keen's paper. On the one hand, Keen argues that endogenous money has long been around in post-Keynesian economics. Despite this, about a third of the article is devoted to a description of endogenous money theory and its mechanics. Keen goes over the claim that 'loans make deposits,' recalls the issue of reverse causation as it applies to bank reserves and bank deposits, and illustrates how reserves move from one bank to another as payments go through the clearing system. Is this part intended to be read by followers of Paul Krugman? On the other hand, Keen tells us that his predecessors have failed to achieve an endogenous money revolution in macroeconomics, and that to do so one

1. See Unlearning Economics (2012) for a summary of the debate and links to the various papers and blog comments. 
needs an overhaul of post-Keynesian macroeconomics that requires 'overturning long established conventions in post-Keynesian economics' (Keen 2014a, p. 290). So here it would seem that the targeted audience is post-Keynesian economists, more precisely those who have emphasized the presence of endogenous money while simultaneously accepting Keynes's definitions and those of the national accounts.

In this comment, I intend to do four things. In Section 2, I examine the 'revolutionary' character of Keen's paper. In Section 3, I examine the antecedents that are being provided by Keen to support his 'revolutionary' claims. In Section 4, I present a postKeynesian author, Alfred Eichner, whom Keen could have used to buttress his case. In Section 5, I present my own balance-sheet account of the changes entailed by bank loans. I will not deal with the correlations noted by Keen.

\section{THE REVOLUTIONARY ELEMENTS OF KEEN}

The revolutionary character of Keen's analysis certainly cannot be found in his presentation of endogenous money. There is nothing new here, except an odd use of T-accounts. In his conclusion, Keen claims that 'the development of endogenous money was a major contribution by post-Keynesian economists from Basil Moore on' (Keen 2014a, p. 290). Keen could have mentioned earlier contributors such as Nicholas Kaldor (1970; 1982) or Joan Robinson (1956; 1970) and her admirer Jacques Le Bourva (1962). On the issue of reversed causation, with money deposit aggregates causing reserve aggregates, Keen found an interesting 2012 quote from the ECB that asserts plainly that the Eurosystem accommodates the demand for central bank reserves at all times, thus providing explicit support for the horizontalist endogenous money position. Otherwise, Keen seems to be making a lot of mileage by quoting a 1969 paper by a former vice-president of the New York Federal Reserve, but this quote could already be found more than 25 years ago in Moore's book (1988, p. 90), along with many other quotes from Fed officials. Thus, overall, on endogenous money and reverse causation, one can only say that Keen is a Johnny-come-lately, as Milton Friedman (mistakenly) once called Kaldor (Kaldor 1982, p. 33).

Besides the claim that 'a truly monetary macroeconomics ... must incorporate the FIRE sector in its analysis' (Keen 2014a, p. 284), the revolution that Keen wishes to bring about is based on one or all of the following equations, which can be found in words or in equations throughout his paper, or throughout Keen's previous papers:

$$
\begin{gathered}
A D=Y+\Delta D \\
A D=Y_{-1}+\Delta D \\
A D=Y_{-1}+v \Delta D,
\end{gathered}
$$

where $A D$ is aggregate demand, $Y$ is income, $Y_{-1}$ is income of the previous period, $D$ is (bank) debt, and $v$ is the 'turnover of new debt.'

As Keen himself says, 'many post-Keynesian economists [see] an obvious double-counting error in the proposition that effective demand can exceed income' (Keen 2014a, p. 272). The proposition has been stated most clearly as 'aggregate demand is the sum of income plus the change in debt' (Keen 2012a, p. 8), which is equation (1a). While these statements have seduced a number of observers, including academic ones, they have attracted a lot of critiques. When he refers to antecedents to his proposition, what Keen seems to rely upon is equation (1b), where 
aggregate demand is equal to income at the end of the previous period (or at the beginning of the current period), plus the change in debt. We shall look at this interpretation in the next section.

Keen (2014a, p. 271) says that 'effective demand is equal to income plus the turnover of new debt,' although mathematically what he is really saying is that current aggregate demand is equal to income of the previous period plus the turnover of new debt, which is equation (1c) above. Further into the paper, Keen writes that his equations imply that 'ex post expenditure equals ex ante income, plus the velocity of money multiplied by the ex post change in debt' (ibid., p. 284), something that, in a somewhat similar paper, Keen $(2014$ b, p. 12, italics in original) was describing as 'aggregate demand in a given period is the sum of aggregate demand at the beginning of that period plus the change in debt over the period multiplied by the velocity of money.' Keen insists that $v$ in equation (1c) is not a constant, in contrast to Friedman's monetarism. But if it is not, then it is no more useful than the equation of exchange, since equation (1c) becomes a truism, a tautology, where $v$ becomes identified after the fact, as a residual. This variant is also identical to the equations proposed by Richard Werner (2006), whose ideas align with some sort of 'credit monetarism.'

Thus, overall, Keen wishes to revolutionize monetary macroeconomics by claiming that 'the equality of income and expenditure and hence of savings and investment must be modified for a model of capitalism with growth in which banks endogenously create money' (Keen 2014a, p. 271). Thus Keen's revolution seems to rely on the claim that investment is equal to saving plus the creation of money.

\section{MINSKY AND KEYNES AS ANTECEDENTS TO KEEN}

\subsection{Loanable funds}

Keen wishes to distinguish his version of endogenous money from one where the loanable funds theory would still hold, claiming that some variant of equation (1) will pull the trick. The loanable funds approach can take several guises. Wicksell can be taken as the major exponent of the loanable funds approach, despite his association with endogenous money and his pure credit economy. Wicksell makes a distinction between money interest rates and the natural rate of interest, the latter being said to reflect the forces of productivity and thrift, determined by the equality between real investment and saving lent in kind. When the money rate of interest is below the natural rate, investment exceeds saving and the difference is taken over by a net monetary creation. Another variant can be associated with Ohlin and Robertson, and their concepts of 'planned saving' or ex ante saving. As pointed out by Bibow (2009, p. 57, italics in original), neo-Walrasians embraced this concept, forgetting to tell us "how planned saving out of expected future incomes may possibly provide the money which the investor needs today.' In the Robertsonian version, there is a lag between income and expenditures: income earned today can only be spent tomorrow, so that planned or ex ante saving refers to saving in the current period out of income from the previous period.

Keen spends a considerable amount of space claiming that contemporary fellow postKeynesians have not accepted that changes in the level of debt play an integral role in aggregate demand. It should be pointed out that the above statement is not the same as claiming that 'aggregate demand is equal to income plus the change in debt' or that 
'aggregate demand is equal to income plus the change in money.' One could certainly accept that bank lending plays a crucial role for aggregate demand without accepting any variant of equation (1). ${ }^{2}$

\subsection{Minsky}

Keen says that, by contrast, a few luminaries in the past- namely Pigou, Schumpeter, Minsky, and Keynes - have recognized the validity of Keen's crucial innovation, given by equations (1). A considerable amount of space is devoted to a 'mathematical proof' provided by Minsky (1975) in his book John Maynard Keynes. I read the book back in 1977, and just like Keen I was intrigued by the algebraic passage he has reproduced in his paper.

But on reflection, what Minsky (1975, pp. 133-136) has 'demonstrated' is just another tautology. If one looks carefully at Minsky's previous definitions, one realizes that the condition that is needed for income to grow, presented in Keen as inequality (1.6), simply says that investment today needs to be larger than saving yesterday. This implies that investment today is larger than investment yesterday. For given parameter values, this must also imply that income today will be larger than income yesterday. No wonder inequality (1.6) implies that income grows! Furthermore, all this also means that saving today will be larger than saving yesterday. Hence, recalling that Minsky assumes that there is an incremental demand for money, represented by Minsky's parameter $(1-u)$ (which is identical to Davidson's (1972) parameter $m$ ), this also implies that the addition to money balances today will be greater than the addition to money balances yesterday. This is what equation (1.8) in Keen (2014a) is restating: the increase in money balances today is greater than the increase in money balances yesterday. There is nothing mysterious about the condition for growth or about the additional money. Devoid of time subscripts, Minsky is saying that investment is being partially financed by the incremental demand for bonds, and that the difference between the two aggregates must be the incremental demand for money. There is nothing controversial about this.

In my opinion, Bernardo and Campiglio (2013) provide a good assessment of the controversy over national accounting that Keen got started. They point out that equation (1a) is counter-intuitive because it is inconsistent with national accounting, which deals with ex post definitions where aggregate expenditure is equal to aggregate income by definition. ${ }^{3}$ Bernardo and Campiglio assert that Keen's claims can only make some sense if a Robertsonian time lag is introduced. They say that what Keen must have in mind is instead equation (1b).

For Bernardo and Campiglio (2013) planned consumption at time $t$ depends on income at time $t$. However realized consumption expenditure at time $t+1$ is equal to planned consumption expenditure at time $t$; in other words, realized consumption at time $t+1$ depends on income at time $t$. Similarly, realized investment at time $t+1$ is in part financed by realized retained earnings at time $t$. Because ex post investment is by necessity equal to ex post saving, in the case where households spend all their disposable income, it is obvious that a rising level of investment, and hence a rising level of aggregate demand, has to be financed by an increase in bank lending, so that equation (1b) applies. This is also what Minsky (1975, p. 135) had in mind when

2. For instance, in the Levy model, set up by Wynne Godley and updated by Gennaro Zezza, private expenditures are a function of income, past wealth, and current new lending. Thus the change in debt plays a crucial role.

3. See also Ramanan (2012), among others, on this inconsistency. 
he says: 'Let us write planned consumption at any date, $t$, as being due to the previous period's income of households from wages and capital.' What he means is that realized consumption at time $t+1$ depends on income at time $t$, as in Bernardo and Campiglio. Indeed, it was long ago pointed out by Mondello (1985) that Minsky's (1975, pp. 131-135) little algebraic model was a Robertsonian one, in the sense that past saving, or ex ante saving, is financing current investment.

\subsection{Keynes}

In his contribution, Keen quotes passages from Keynes's debate with Ohlin. I doubt that these provide any support to Keen's position. In this debate, Keynes (1973, pp. 201-223) was rather critical of the use of ex post, ex ante, and ex anything. ${ }^{4}$ Indeed, in a letter to Ohlin, Keynes (1973, pp. 184-185) explains that although he used to be 'thinking and lecturing somewhere about 1931 and 1932' along the lines of 'the ex post and ex ante method,' he 'subsequently abandoned' this line of thought. The reason, as he explained to Ohlin, was 'when one comes to prove something truly logical and properly watertight' then the 'ex post and ex ante device cannot be precisely stated without some very cumbrous devices,' so that 'at any given time there was no aggregate realised result capable of being compared with some aggregate expectation at some earlier date.' In simple terms, these time lags appear to be arbitrary. It is somewhat ironic that Keen is resorting to $e x$ ante and ex post arguments to differentiate his views from that of the loanable funds model, when constructs such as ex ante saving were one of the coping stones of some variants of the loanable funds model, as I mentioned earlier.

The main point that Keynes is trying to make in his debate with Ohlin and Robertson is that one must carefully distinguish between what Graziani (1990) later called initial finance and final finance, where the former is the bank deposits needed to make a transaction, whereas the latter is saving as defined by the national accounts. ${ }^{5}$ Initial finance is often the bank loan provided to start production, whether it occurs in the investment or in the consumption sectors. As Keynes (1973, p. 282) put it, back in 1939, 'it is not an increase of investment as such which requires an immediate increase in "available funds", but an increase of output whether for investment or for consumption.'

\section{AN ALTERNATIVE ANTECEDENT}

Keen provides a few short quotes from Schumpeter to convince us that aggregate demand is the sum of income and the change in debt. Once again I did not find these statements compelling. What they show is the importance of bank credit for creating new purchasing power, a feature of Schumpeter's vision which has long been emphasized by monetary circuit theorists. This was also emphasized in Schumpeter's History of Economic Analysis (1954), in particular in the following statement: '[The existence of banks] alters the analytic situation profoundly and makes it highly inadvisable to

4. He was particularly critical of the use of ex ante saving: 'As far as the concept of ex ante saving, I can attach no sound sense to it' (Keynes 1973, p. 210).

5. Initial finance was presented by Keynes as the finance motive. A huge post-Keynesian literature, which goes back to the mid 1960s and which is summarized by Bibow $(2009$, ch. 2), has examined the meaning of the finance motive and its link with bank credit. Also, besides Bibow (2009, ch. 3), see Lindner (2013) and Bertocco (2013) for recent restatements of Keynes's position and a critique of the loanable funds theory. 
construe bank credit on the model of existing funds being withdrawn from previous uses by an entirely imaginary act of saving and then lent out by their owners. It is much more realistic to say that the banks "create credit", that is, that they create deposits in their act of lending, than to say that they lend the deposits that have been entrusted to them' (ibid., p. 1114). Thus what Schumpeter is really saying is that credits make deposits, as post-Keynesians have been arguing for a long time.

The author that Keen could have recruited to provide support for his arguments is Alfred Eichner. While Eichner is especially known for his work on the microeconomics of large corporations, he has also made crucial contributions to the understanding of monetary economics and the operations of central banks, being a notable advocate of reversed causation with respect to the link between bank deposits and reserves (Lavoie et al. 2010). While also underlining the importance of sectoral financial balances summing to zero in his 1987 book, Eichner (1987, p. 84) points out that 'under a credit-based system of money, an increase in the amount of funds in circulation will occur as an endogenous response whenever one of the nonfinancial sectors uses loans from the banking system to finance its outlays,' so that it is an error 'to assume that an improvement in the financial position of any one sector must necessarily be at the expense of some other sector - and thus that the overall amount of funds in circulation is fixed.'

Eichner (ibid., p. 836), like Keynes before him, is quite clear that additional saving will not provide the finance which is required for production: 'Should a nonfinancial sector reduce its current outlays as the means it has chosen to increase its net savings, the gross income of some other nonfinancial sector will necessarily fall by the same amount.' Thus, as a result of this, 'the banking system, rather than gaining deposits as a result of the net increase in savings by the one financial sector, will be left with the same amount of deposits as before. This is because the reduction in the gross income of the other sector will reduce that sector's bank balance' (ibid., p. 832). Thus, Eichner concludes that 'it is only if and when that other sector arranges for a bank loan to cover the involuntary deficit it has incurred that the total amount of checkable deposits within the banking system will increase' (ibid., p. 832). Eichner then clearly argues that investment determines saving - a presupposition among all post-Keynesians: 'the only way to increase aggregate savings is through a prior increase in investment and other discretionary expenditures, with bank credit providing the necessary interim finance' (ibid., p. 838, my emphasis). So far so good; but then Eichner moves towards the position defended by Keen, as the following quote shows:

To the extent that expenditures can be financed, not out of current income but rather, through bank credit, the level of sales at any one moment of time is not limited to the amount of income flowing into each of the nonfinancial sectors. Sales to one of the nonfinancial sectors can exceed that sector's current income, or total cash inflow, by the amount the sector is willing and able to increase its debt to the banking system. Indeed, it is the possibility of the nonfinancial sectors being able to make credit-financed purchases that, by relaxing the income constraint that would otherwise preclude any such possibility, explains how the level of national income can increase from one period to the next. (Eichner 1987, p. 838)

Pursuing this line of thought, Eichner concludes that 'the level of income ... will increase by the amount of additional credit obtained from the banking system.' This is what will be observed in the case of Table 2 (shown in Section 5), when firms increase production and their wage bill without initially being able to sell their additional production and hence being forced to increase their inventories. However, as will be observed in Table 1 (also in Section 5), such a statement is not valid if the additional amount of credit is obtained by consumers. Furthermore, as argued by Kalecki $(1954$, p. 50) and as 
recently reasserted by Jan Toporowski (2012), if 'additional investment is financed by bank credit, the spending of the amounts in question will cause equal amounts of saved profits to accumulate as bank deposits.' The firms that have produced and sold the investment goods can thus decrease their debt pari passu, so that we cannot say that the increase in income is equal to the increase in bank loans.

At the end of the section devoted to the endogeneity of money, Eichner (1987, pp. 839-840) comes up with a statement identical to that of Keen (2012b), as Eichner writes that 'the level of aggregate demand, will necessarily be equal to the level of national income in that period ... plus the increase in the amount of bank credit ... with the level of national income rising in the next period to match the level of aggregate demand. ${ }^{6}$ The last part of the sentence reveals that Eichner also has some time lag in mind, and hence his views on bank credit and saving, despite their initial and useful representation through a flow-of-funds analysis, are ultimately no different from those of Keen, Minsky, and Bernardo and Campiglio.

\section{BANK LOANS AND ACCOUNTING}

The purpose of this last section is to show that national accounting makes sense and that equations (1) are neither correct nor useful, whether one uses continuous or discrete time, or whether one makes use of discontinuities. I am employing an alternative presentation of T-accounts, with simple numbers, which I hope are easier to follow than those put forward by Keen.

\subsection{Bank loans to consumers}

Let us first examine the case where households get a bank loan. This is shown in Table 1. The first line of Table 1 illustrates the well-known 'credits make deposits' aphorism. The additional debt and stock of money are equal to each other, here shown at \$10. But suppose now that debtor households decide to spend all their additional cash-flow, by purchasing consumer goods. Assume further that consumer goods priced at $\$ 10$ cost $\$ 7$ to produce. The second line of Table 1 illustrates the new situation. Bank loans are still equal to bank deposits, but the latter have changed hands. The firm has sold a good to the debtor household for $\$ 10$, thus reducing the value of its inventories by $\$ 7$ and pocketing a profit of $\$ 3$, which increases the net worth of the firm by the same amount. The consumer loan made by the bank has had an impact on the economy, in contrast to consumer debt provided through the bond market (which was shown in the first line of Table 1 in Keen 2014a).

What will the national accounts tell us? Equation (2) describes the relationship between: production (GDP) and income, given by $Y$; sales or final spending, given by $F S$; and the value of the change in inventories, $\Delta I N$. For the national accountants, GDP seen from the expenditure side is equal to final spending plus the value of the

6. Eichner (1987, p. 837) introduces a table with a numerical example, which he says is adapted from Godley and Cripps (1983, pp. 62-63). The table is in fact quite different from that of Godley and Cripps. Eichner starts the table by assuming that sales rise by $\$ 150$, thanks to an increase in bank credit of $\$ 150$, while income remains constant. Only in the next period do production and income adjust to this additional spending. Besides the introduction of a time lag, there is no account of changes in inventories and the consequent effect that they might have on the debt of the producers. 
Table 1 A bank loan to consumers

\begin{tabular}{|c|c|c|c|c|c|}
\hline \multicolumn{2}{|c|}{ Households (HH) } & \multicolumn{2}{|c|}{ Banks } & \multicolumn{2}{|c|}{ Non-financial firms (NFF) } \\
\hline Assets & Liabilities & Assets & Liabilities & Assets & Liabilities \\
\hline \multirow[t]{3}{*}{ Deposits +10} & Debt +10 & $\begin{array}{l}\text { Loans to } \\
\text { HH }+10\end{array}$ & $\begin{array}{c}\text { Deposits of } \\
\mathrm{HH}+10\end{array}$ & & \\
\hline & $\begin{array}{l}\text { Debt }+10 \\
\text { Net worth }-10\end{array}$ & $\begin{array}{l}\text { Loans to } \\
\qquad \mathrm{HH}+10\end{array}$ & $\begin{array}{r}\text { Deposits of } \\
\text { NFF }+10\end{array}$ & $\begin{array}{l}\text { Deposits }+10 \\
\text { Inventories }-7\end{array}$ & Net worth +3 \\
\hline & $\begin{array}{l}\text { Debt }+10 \\
\text { Net worth }-10\end{array}$ & $\begin{array}{l}\text { Loans to } \\
\text { HH }+10 \\
\text { Loans to } \\
\text { NFF }-10\end{array}$ & $\begin{array}{l}\text { Deposits of } \\
\text { NFF } 0\end{array}$ & Inventories -7 & $\begin{array}{l}\text { Net worth }+3 \\
\text { Loans }-10\end{array}$ \\
\hline Deposits +3 & $\begin{array}{l}\text { Debt }+10 \\
\text { Net worth }-7\end{array}$ & $\begin{array}{l}\text { Loans to } \\
\text { HH }+10 \\
\text { Loans to } \\
\text { NFF }-7\end{array}$ & $\begin{array}{c}\text { Deposits of } \\
\mathrm{HH}+3\end{array}$ & Inventories -7 & Loans -7 \\
\hline
\end{tabular}

change in inventories (which are implicitly being assumed to have been purchased by the producer). ${ }^{7}$

$$
Y=F S+\Delta I N
$$

Final sales $F S$ have increased by $\$ 10$; inventories have fallen by $\$ 7$; therefore GDP has increased by $\$ 3$, which is reflected in the additional $\$ 3$ profit that accrues to the firm. All is well: production is indeed equal to income. Note, however, that the overall debt of the economy has risen by $\$ 10$ while GDP has only risen by $\$ 3$. There is no one-to-one relationship in this case, in contrast to equations (1a) or (1b).

What happens next depends on the actions of the firm. It may decide to use its newly-acquired deposits to reduce its debt to the bank, a case illustrated in the third line of Table 1. In this case, at the end of this process, there has been a reflux of bank deposits, which are now no higher than they were at the very beginning of the process, while the overall increase in the amount of loans in the economy is back to zero, the increase in consumer loans being fully compensated by the reduction in the loans taken by firms. As Keynes said back in 1937, 'consumption is just as effective in liquidating the short-term finance as saving is' (Keynes 1973, p. 221). In other words, 'the production of consumption goods requires the prior provision of funds just as much as does the production of capital goods' (ibid., p. 282), so that the loans taken by firms to start production can be extinguished by the spending of consumers. At this stage, the increase in domestic income is still $\$ 3$, but the overall increase in bank lending is nil.

One could also imagine that firms do not retain the $\$ 3$ profit that they just made, distributing dividends of $\$ 3$ to their shareholders, who add the dividends to their bank deposits. This is shown in the fourth line of Table 1. In this case, relative to

7. If we assume that aggregate demand is represented by sales, or final spending, here noted as $F S$, then it is indeed possible for aggregate demand to exceed income; but this has to be accompanied by a fall in inventories. 
the initial situation just before the consumer loan was granted, the overall (additional) amount of bank deposits will be $\$ 3$, the net increase in loans granted to the private non-financial sector will also be $\$ 3$, while the increase in consumer debt remains at $\$ 10$. Profit recipients may decide in turn to spend part of their dividends, but we will leave it at that, just as we leave aside interest payments on loans and deposits.

\subsection{Bank loans to producers}

So far we have only discussed consumer loans. What about business loans? Why, in our previous example, did firms take bank loans? One could presume that firms have no accumulated retained earnings and that they hold no money balances. Under these assumptions, the relationship between working capital and consumer loans has been studied extensively by Godley and Cripps (1983). To illustrate this, assume that everything produced during the year has been sold, and then that on the last day of the year a firm decides to produce an additional good, worth $\$ 10$ on the marketplace, at a cost of \$7. This is shown with the help of Table 2.

The firm gets a $\$ 7$ bank loan and pays its workers with it. But shops are all closed, because this is New Year's Eve, so households cannot spend any of their newly-earned wages, thus holding their last pay in the form of bank deposits and thus increasing their saving by $\$ 7$. How will that be taken care of, from a national accounting point of view? We use equation (2) once again. Here the increase in GDP (production and income), on the very last day of the year, is equal to the change in inventories, $\$ 7$. Checking Table 2, we see that this also happens to be equal to the change in debt, $\Delta D$, thus giving rise to equation (3), taken from Godley and Cripps:

$$
Y=F S+\Delta D \text {. }
$$

This somewhat resembles various statements made by Keen to the effect that aggregate demand today is equal to aggregate demand yesterday plus the change in debt, or that the change in aggregate demand today is equal to the change in debt, or even that aggregate expenditure on goods and services is equal to income plus the change in debt.

But the statements in equations (2) or (3) are different from equation (1a). Here in equation (2), income is $Y$ and aggregate expenditure is also $Y$, while one could say that aggregate demand is FS. One could also make the following argument: during the first

\section{Table 2 A bank loan to producers}

\begin{tabular}{|c|c|c|c|c|c|}
\hline \multicolumn{2}{|c|}{ Households (HH) } & \multicolumn{2}{|c|}{ Banks } & \multicolumn{2}{|c|}{ Non-financial firms (NFF) } \\
\hline Assets & Liabilities & Assets & Liabilities & Assets & Liabilities \\
\hline Deposits +7 & Net worth +7 & $\begin{array}{l}\text { Loans to } \\
\text { NFF }+7\end{array}$ & $\begin{array}{c}\text { Deposits of } \\
\mathrm{HH}+7\end{array}$ & Inventories +7 & Loans +7 \\
\hline Deposits +2 & Net worth +2 & $\begin{array}{l}\text { Loans to } \\
\qquad \mathrm{NFF}+7\end{array}$ & $\begin{array}{c}\text { Deposits of } \\
\text { HH }+2 \\
\text { Deposits of } \\
\text { NFF }+5\end{array}$ & $\begin{array}{l}\text { Deposits }+5 \\
\text { Inventories }+3.5\end{array}$ & $\begin{array}{l}\text { Loans }+7 \\
\text { Net worth }+1.5\end{array}$ \\
\hline Deposits +2 & Net worth +2 & $\begin{array}{l}\text { Loans to } \\
\text { NFF +2 }\end{array}$ & $\begin{array}{c}\text { Deposits of } \\
\mathrm{HH}+2\end{array}$ & Inventories +3.5 & $\begin{array}{l}\text { Loans }+2 \\
\text { Net worth }+1.5\end{array}$ \\
\hline
\end{tabular}


364 days of the year, sales were equal to production. Production over 365 days is equal to what was produced and sold over the first 364 days plus the change in inventories (equal to the change in debt), so that the change in production over the $365^{\text {th }}$ day is equal to the change in debt. This is not the same as saying that the change in aggregate demand is equal to the change in debt.

If households had managed to rush to the shops just before closing time, spending $\$ 5$ from their ultimate pay, as illustrated in the second line of Table 2, sales would have risen by $\$ 5$ while inventories would have fallen by $\$ 3.5$ relative to the first line, and thus increased by $\$ 3.5$ relative to the situation on the $364^{\text {th }}$ day, thus leading to an overall increase of $\$ 8.5$ in GDP, accompanied by an overall increase in debt of $\$ 7$. If firms reimburse their debt with the proceeds, then the situation is illustrated by the third line of Table 2. Whatever is the case, there is no longer a one-to-one relationship between the change in production and the change in debt, or between the change in final sales and the change in debt.

In general, as Godley and Cripps (1983, p. 83) put it, 'the aggregate-income expenditure flow must always adjust to the point at which people collectively but voluntarily are holding whatever additional money balance has been created.' The additional production, made possible by an increase in bank credit, generates an increase in income and in money balances. Households then decide what proportion of their newly acquired income they wish to spend. But this, in a world where the only asset is bank deposits, means that households decide what proportion of these extra money balances they wish to hold and which proportion they wish to spend.

\section{CONCLUSION}

We are grateful to Steve Keen for having induced Krugman to engage in a public discussion over the role of bank credit and money creation. We are also grateful to Keen for designing a program that helps us to understand the dynamics of an integrated real and financial system. However, reading Keen's paper, one gets the impression that he has discovered something fundamental about bank credit, something that previous and current post-Keynesian economists were not really aware of. I would argue instead that contemporary post-Keynesian authors, along with monetary circuit authors, have long been cognizant of the importance of bank credit and its impact, notably through their discussions about the relevance of Keynes's finance motive, from the mid 1960s until now, as well as their insistence that saving does not finance production while credit does. I don't think that the way forward is to go back and get trapped in the Swedish or Robertsonian time-lag analysis.

All post-Keynesians certainly concur with the idea that banks have the capacity to alter the level of aggregate demand, and hence that it would be desirable for banks, debt, and money to be included in models of macroeconomics. Indeed, one could argue that it was this realization that led Eichner (1987) to write down the equivalent of equation (1a) or (1b). There are several examples of post-Keynesian macroeconomic models that incorporate banks, debt, and money - for instance, Godley and Cripps (1983) and Godley and Lavoie (2007), just to mention those that I am most familiar with. For practical and pedagogical reasons, not all post-Keynesian models respond to such strictures: several models do not attempt to integrate the real and the financial sides of the economy, or they leave aside the role of non-bank financial intermediaries. But this does not imply, as Keen claims, that we need a redefinition of aggregate demand such that the starting point of macroeconomics is that 'effective 
demand is equal to income plus the turnover of new debt' (Keen 2014a, p. 286). Nor does it mean that aggregate supply needs to be redefined 'to incorporate the financial markets' (ibid., p. 290). ${ }^{8}$ To provide new definitions of existing terms will only lead to a maze of confusions.

Keen makes the grandiose claim that his approach leads to a 'new, monetary macroeconomics' (Keen 2014a, p. 286). While statements of this kind may appeal to an internet audience, I doubt they will convince readers of this journal.

\section{REFERENCES}

Bernardo, G. and E. Campiglio (2013), 'A simple model of income, aggregate demand, and the process of credit creation by private banks,' http://www.levyinstitute.org/publications/? docid $=1905$.

Bertocco, G. (2013), 'On Keynes's criticism of the loanable funds theory,' Review of Political Economy, 25 (2), 309-326.

Bibow, J. (2009), Keynes and Monetary Policy, Finance and Uncertainty, London: Routledge. Davidson, P. (1972), Money and the Real World, London: Macmillan.

Eichner, A.S. (1987), The Macrodynamics of Advanced Market Economies, Armonk: M.E. Sharpe.

Godley, W. and F. Cripps (1983), Macroeconomics, London: Fontana.

Godley, W. and M. Lavoie (2007), Monetary Macroeconomics: An Integrated Approach to Credit, Money, Income, Production and Wealth, Basingstoke: Palgrave Macmillan.

Graziani, A. (1990), 'The theory of the monetary circuit', Économies et Sociétés, 24 (7), 7-36.

Kaldor, N. (1970), 'The new monetarism', Lloyds Bank Review, July, 1-17.

Kaldor, N. (1982), The Scourge of Monetarism, Oxford: Oxford University Press.

Kalecki, M. (1954), Theory of Economic Dynamics, London: Allen and Unwin.

Keen, S. (2012a), 'A primer on Minsky,' http://www.economonitor.com/blog/2012/03/a-primeron-minsky/.

Keen, S. (2012b), 'Instability in financial markets: sources and remedies,' http://ineteconomics. org/sites/inet.civicactions.net/files/keen-steve-berlin-paper.pdf.

Keen, S. (2014a), 'Endogenous money and effective demand,' Review of Keynesian Economics, 2 (3), 271-291.

Keen, S. (2014b), 'Modeling financial instability,' http://www.debtdeflation.com/blogs/wpcontent/uploads/2014/02/Keen2014ModelingFinancialInstability.pdf.

Keynes, J.M. (1973), The Collected Writings of John Maynard Keynes, volume 14, London: Macmillan.

Lavoie, M. (1985), 'Credit and money: the dynamic circuit, overdraft economics, and Post Keynesian economics.' In M. Jarsulic (ed), Money and Macro Policy, Boston: KluwerNijhoff, pp. 63-84.

Lavoie, M., L.-P. Rochon and M. Seccareccia (2010), Money and Macrodynamics: Alfred Eichner and Post-Keynesian Economics, Armonk: M.E. Sharpe.

Le Bourva, J. (1962), 'Création de la monnaie et multiplicateur de crédit,' Revue Économique, $13(1), 29-56$.

Lindner, F. (2013), 'Does saving increase the supply of credit? A critique of loanable funds theory,' http://www.boeckler.de/pdf/p_imk_wp_120_2013.

Minsky, H.P. (1975), John Maynard Keynes, New York: Columbia University Press.

Mondello, G. (1985), 'L'importance de la notion de finance dans la théorie monétaire de J.M. Keynes.' In R. Arena, A. Graziani and J. Kregel (eds), Production, Circulation et Monnaie, Paris: Presses Universitaires de France, pp. 387-410.

8. Godley and Cripps (1983, p. 85) pointed out a long time ago that 'some borrowing may be undertaken purely for the purpose of, or as a counterpart to, the holdings of financial assets,' and this can be the case both for 'private individuals and non-financial businesses.' But this did not lead them to turn the definitions of aggregate demand and aggregate supply upside-down. 
332 Review of Keynesian Economics, Vol. 2 No. 3

Moore, B.J. (1988), Horizontalists and Verticalists: The Macroeconomics of Credit Money, Cambridge, UK: Cambridge University Press.

Ramanan, V. 'Income $\neq$ Expenditure,' http://www.concertedaction.com/2012/10/06/income-\% E2\%89\%A0-expenditure/.

Robinson, J. (1956), The Accumulation of Capital, London: Macmillan.

Robinson, J. (1970), 'Quantity theories old and new,' Journal of Money, Credit and Banking, 2 (4), 504-512.

Schumpeter, J.A. (1954), History of Economic Analysis, New York: Oxford University Press.

Toporowski, J. (2012), 'Corporate liquidity and financial fragility: the role of investment, debt and interest,' SOAS Department of Economics working paper 169, http://www.soas.ac.uk/ economics/research/workingpapers/file74886.pdf.

Unlearning Economics (2012), 'The Keen/Krugman debate: a summary,' http://unlearning economics.wordpress.com/2012/04/03/the-keenkrugman-debate-a-summary/.

Werner, R.A. (2006), New Paradigm in Macroeconomics, Basingstoke: Palgrave Macmillan. 